$\left(\begin{array}{l}\text { Jpn. J. Hosp. Pharm. } \\ 25(1) \quad 60-64 \\ -699)\end{array}\right)$

ワルファリンによると考えられる薬剤性肝機能障害の一例

橋本博史 ${ }^{*} \dagger^{1}$ ，上野和行 $\dagger^{1}$ ，平木精一 $\dagger^{1}$, 高田充隆 $\dagger^{1}$ ，松尾汎 $\dagger^{2}$ ，柴川雅彦 $\dagger^{1}$

国立循環器病センター薬剤部 $\dagger^{1}$, 同内科 $\dagger^{2}$

\title{
A Case of Hepatic Failure Due to the Administration of Warfarin
}

\author{
HIROSHI HASHIMOTO $* \dagger^{1}, \quad$ KAZUYUKI UENO $\dagger^{1}$, KIYOKAZU HIRAKI $\dagger^{1}$, MITSUTAKA TAKADA $\dagger^{1}$ \\ HIROSHI MATSUO $\dagger^{2}$ and MASAHIKO SHIBAKAWA $\dagger^{1}$ \\ Department of Pharmacy $\dagger^{1}$ and Internal Medicine ${ }^{2}$, National Cardiovascular Center
}

$$
\left(\begin{array}{lll}
\text { Received July } 24, & 1998 & \\
\text { Accepted November } 11, & 1998
\end{array}\right)
$$

A 61-year-old woman weighting $57.9 \mathrm{~kg}$ was hospitalized with deep vein thrombosis. She received warfarin therapy. At first $2 \mathrm{mg}$ /day of warfarin was administered for five days while from the 6 th day the dose was increased to $3 \mathrm{mg} /$ day. From the 8 th day the dose was increased to 4 $\mathrm{mg} /$ day. Although the GOT and GPT value was within the normal range before the warfarin therapy was started, on the 5 th day after the therapy was started the GOT and GPT levels were 68 and $61 \mathrm{Iu} / 1$, respectively, while on the 12 th day the GOT and GPT had increased even more ( 99 and 212). We consider such hepatic evidence to be due to the administration of warfarin and its administration was thus stopped. On the 4 th day after warfarin was stopped the GOT and GPT levels decreased to 55 and 128, respectively, and after that it decreased even more. Both the GOT and GPT decreased to the normal range within one month. On the other hand, in order to evaluate an allergy to warfarin, a patch test of warfarin was examined, however, the results of the test was negative. No reports of hepatic failure due to the administration of warfarin could be found on Medline from 1966 to February 1998. These results suggest this case to be a very rare one, however, further study is called for in the future.

Key words - warfarin, side effect, hepatic failure

\section{緒言}

経口抗凝血薬であるワルファリン（WF）は， 抗凝固療法として心䈘梗塞, 一過性脳虚血の治療 を主とする短期療法, あるいは再発予防を目的と した長期療法, それらの血栓塞栓症の予防などに 幅広く使用されている.WFの副作用としては,

$\dagger^{1,2}$ 大阪府吹田市藤白台5-7-1；5-7-1， Fujishirodai， Suita, Osaka, 565-8565 Japan
血液凝固系の異常に基づいて出現するもの，つま り出血に関するものが報告されている ${ }^{1-9)}$. また, 他の薬剤との併用による相互作用で, 作用の増強 や減弱がみられたとの報告がなされている ${ }^{6-16)}$. しかしながら，WFによる肝機能障害についての 報告は非常に少ない ${ }^{18-22)}$. 今回, 深部静脈血栓塞 栓症の抗凝固療法として, WF が投与されたが 徐々にグルタミン酸オキザロ酢酸トランスアミ ナーゼ $(\mathrm{GOT})$, グルタミン酸ピルビン酸トラン 


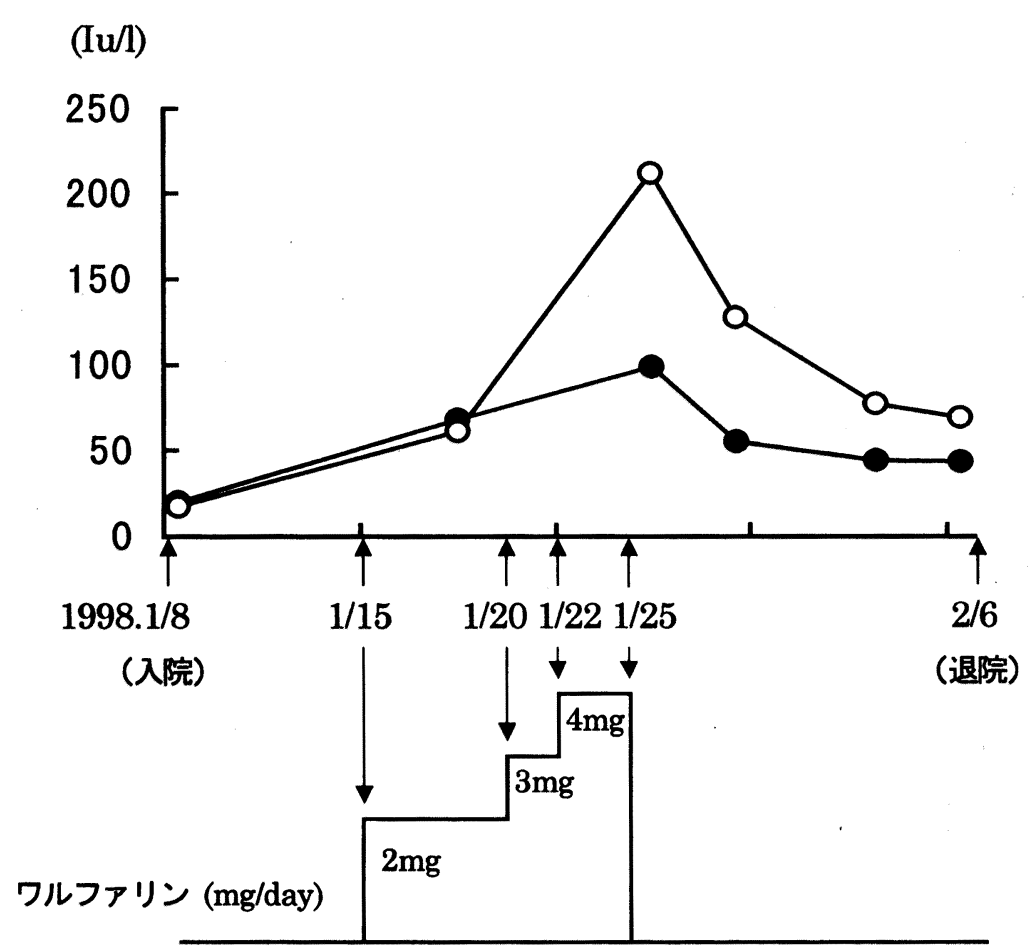

図 1.ワルファリン投与量と GOT および GPT の関係 - GOT -

スアミナーゼ（GPT）の上昇がみられ，10日後に 顕著な上昇を呈したため, WF の投与を中止せざ るを得なくなった症例を経験した。 かつ本症例の 肝機能障害は, 投与直後から急激な GOT, GPT の上昇を伴うアレルギー性というより，WF の血 中濃度依存的とも考えられたため, WFによるア レルギー反応の評価のためにパッチテストも行っ たのでその詳細を報告する.

\section{症例}

症例は，61歳女性．97年11月25日から左下腿が 腫脹, 医療機関にて静脈疾患を疑われて12月 1 日 ～12月12日入院し, 抗生剤とアルガトロバンの点 滴静注を受け一時的に軽快していたが，98年 1 月 から腫脹が再発し，98年 1 月 7 日当センター受診 し，1月 8 日入院した。入院時身長 $162 \mathrm{~cm}$, 体重 $57.9 \mathrm{~kg}$, 血圧 $110 / 60 \mathrm{mmHg}$, 脈拍 70 . 心肺雑音な
し. 左下腿に浮腫と軽度の熱感を認めるが, 色素 沈着や静脈瘤を認めなかった。入院精査の結果, 深部静脈塞栓症および血栓症（腸骨，大腿，膝 窩, 下腿の静脈）の診断がされた。リスク要因, 高血圧 (一), 糖尿病 (一), 高脂血症 (一), た ばこ(一), 酒 (一). 入院からの GOT, GPTの 検査データ, WF の投薬歴を図 1 に示した。 入院 時 1 月 9 日 GOT 20Iu/ 1 , GPT $17 \mathrm{Iu} / 1$ と正常值 であった. 深部静脈血栓症の治療として 1 月 9 日 よりアルガトロバン $10 \mathrm{mg} \times 2 /$ 日の治療が始めら れ 1 月14日からヘパリンナトリウム $12000 \mathrm{u} /$ 日に 切り替えられた。また翌日 1 月15日より WF 2 $\mathrm{mg} /$ 日が開始され，1月20日より WF $3 \mathrm{mg} /$ 日に 増量になった。この時点で GOT68Iu/1，GPT61Iu/ 1 と入院時 1 月 9 日に比べ軽度の上昇をみた。 1 月22日よりさらに WF $4 \mathrm{mg} /$ 日の増量になった。 増量 5 日後 1 月 26 日の血液検查結果では, GOT 
$99 \mathrm{Iu} / 1$, GPT $212 \mathrm{Iu} / 1$ と薬物性肝機能障害を疑 わせる更なる GPT 優位の高度な上昇をみた。そ こでWFによる肝機能障害を疑い，1月26日投与 中止となった. 中止 4 日後 1 月29日の血液検査結 果は GOT $55 \mathrm{Iu} / 1$ ，GPT $128 \mathrm{Iu} / 1$ と下降をみせ た. 1 月30日より退院後の治療に備え, 同じへパ リン製剤であるへパリンカルシウムの $6000 \mathrm{u} \times 2$ / 日の自己注射に変更となった． 2 月 3 日の血液検 査結果では GOT $44 \mathrm{Iu} / 1$ ， GPT $77 \mathrm{Iu} / 1$ と更なる 下降をみせた。 2 月 4 日シロスタゾール $100 \mathrm{mg} \times$ 2 /日が追加され 2 月 6 日退院となった. 投与中 止 1 力月後の血液検查結果は, GOT $22 \mathrm{Iu} / 1$, GPT $19 \mathrm{Iu} / 1$ と入院前に回復していた.

\section{方法}

\section{1.メッドラインによる検索}

今回，本症例を経験し，WFによる肝機能障害 の報告例を検索するべく , メッドラインを使って 検索した。検索期間は，1966１998年 2 月とし た。検索キーワードは, (1) warfarin, (2) adverse effect, (3) side effect, (4) liver disease, (5) liver failure, (6) hepatic disease, (7) hepatic failure とした.

2.. パッチテスト

本症例の肝機能障害は, WF の投与時期, 投与 量から判断し WF の血中濃度依存的とも考えられ た。しかし，アレルギー反応による肝機能障害へ
の副作用を調べるためパッチテストを実施した. 実施に際して，パッチテストの意義とその安全性 を書面にて説明し，パッチテストの同意を得た。 パッチテスト実施は, 退院後 2 力月の 4 月 6 日に 行った。方法は，WF を種々の濃度に調製した溶 液に濾紙にてしみ込ませ，これを被験者の下腕部 に貼付し，48時間後の皮虐症状を観察した。WF 濃度は一般に経口時最高血中濃度は約 $10 \mu \mathrm{g} / \mathrm{ml}$ であること，蛋白結合率は97〜99\%であることを 考慮 ${ }^{17)}$ して，10，100，および $1000 \mu \mathrm{g} / \mathrm{ml}$ に調製 した。調製法は，WF原末を局方エタノールに溶 解しエタノール濃度10\%になるように精製水で希 釈，各濃度の溶液を調製した。一方，WF は， S と $\mathrm{R}$ の光学異性体が知られているので, 溶液は $\mathrm{S}$ および $\mathrm{R}$ 体を調製した。また，WF 錠の賦形薬の 影響も調べるべく，WF 錠より調製した溶液につ いても検討を行った．対照は生理食塩液および 10\%エタノール溶液を用いた。なお，本研究に用 いた試薬類は，すべて特級試薬（和光純薬）を用 い,またWFの原末についてはエーザイ株式会社 より提供を受けた。

\section{結果}

\section{1.メッドラインによる検索結果}

WF に関するメッドライン検索の結果を表 1 に 示した，1966年より1998年 2 月まで6352件の報告

表 1.メッドラインによる検索結果

\begin{tabular}{|c|c|c|c|c|}
\hline \multirow{2}{*}{ 調査期間(年. 月) } & \multicolumn{4}{|c|}{ キーワード } \\
\hline & (1) & (1) and (2) or (3)) & (1) and (4) or (5)) & (1) and (6) or (7) \\
\hline '66 ' 82 & 2221 & 3 & 8 & 1 \\
\hline '83 ' 89 & 1490 & 8 & 21 & 2 \\
\hline 1990 & 259 & 1 & 0 & 0 \\
\hline 1991 & 269 & 2 & 2 & 1 \\
\hline '92 ’'96 & 1577 & 13 & 11 & 1 \\
\hline '97.1 '97.9 & 337 & 0 & 0 & 1 \\
\hline '97.10 '98.1 & 164 & 1 & 0 & 0 \\
\hline '98.1 ’'98.2 & 35 & 1 & 0 & 0 \\
\hline
\end{tabular}

$\begin{array}{lllll}\text { 検索キーワード (1) warfarin (2) adverse effect } & \text { (3) side effect } & \text { (4) liver disease }\end{array}$

(5) liver failure (6) hepatic disease (7) hepatic failure 
があったが，(1) warfarinan and ((2) adverse effect or (3) side effect) で29件, (1) warfarin and (4) liver disease or (5) liver failure) 42件, (1) warfarin and (6) hepatic disease or (7) hepatic failure) で 6 件であった。これら77件の報告を調査すること で, 今回の肝機能障害を検証した。77件の報告 は，WF 併用による薬物相互作用，体内動態への 影響が 7 件 ${ }^{10-16)}$, それに伴う出血報告が 4 件 ${ }^{6-9)}$, WF 投与中の出血報告が 5 件 $^{1-5)}$ であった. 残りの 61件の報告は，検索キーワードに掛かったが肝機 能障害とは無関係であった。メッドラインによる 検索結果では，WF 単独によると考えられる薬物 性肝機能障害の報告はなかった。

\section{2. パッチテストによる結果}

48時間後, 各種 WF 濃度調製溶液, 対照液の パッチはともに未変化で判定は陰性であった。ま た, GOT, GPT には変化はなかった.

\section{考察}

薬剤性肝障害には, 発生機序よりアレルギー性 のものつまり患者側の因子に起因するものと, 薬 率自体あるいは，その代謝産物によって肝細胞障 害が起こる直接肝障害に分けられる。本症例は WF 投与後徐々にGOT, GPT の上昇がみられ, WF の血中濃度の定常に達する約 1 週間頃に顕著 な上昇を呈し WFの投与を中止せざるを得なく なった症例であった。併用薬㓮は，ヘパリンのみ であったが WF 投与の前から使用されへパリン単 独では, GOT, GPTの上昇は認められなかった。 かつWF中止後もへパリンは継続されたが GOT, GPTは，徐々に下降し正常域に戻った。 また, 他の血液検查結果等過敏諸因子による異常 が認められなかったことにより特異的な肝機能障 害は考えにくい。一方，パッチテストの結果をも 考虑すれば，本症例の肝機能障害はアレルギー反 応というよりもむしろ WF の血中濃度依存的と考 えられた。また，WF $4 \mathrm{mg}$ に増量 5 日後の INR 值が1.27であることから WF の代謝異常による血 中濃度の異常上昇による可能性も考えにくい，し
たがって, 本症例は，WF 単独による肝機能障害 と示唆される。一般にWF 単独による副作用とし て肝機能障害の報告は非常に少なく, かつ今回, メッドラインによる検索を行ったが報告は認めら れなかった。しかし，従来の報告18-22)はすべて WF 投与による経時的な GOT, GPT の上昇が認 められることを考えればWFによる肝機能障害 は，血中濃度依存的な副作用と考えられる．本症 例は，非常にまれな症例である。しかし今後 WF による肝機能障害に関しても，十分注意しなけれ ばならないことが示唆された。

\section{引用文献}

1) Albers-GW, Am. J. Cardiol., 23, 75, 34 B-38 B (1995).

2) Avent-ML , Canaday-BR , Sawyer-WT , Clin Pharm., 11, 632-635 (1992).

3) Carter-BL, Jones-ME, Waickman-LA, Clin . Pharm., 4, 279-296 (1985).

4) Friedland-ML,Wittels-EG,Postgrad.Med. J., 58, 39-40 (1982).

5) Landefeld-CS, Beyth-RJ, Am.J. Med., 95, 315328 (1993).

6) Yip-AS, Chow-WH, Tai-YT, Cheung-KL, Postgrad. Med. J., 66, 367-369 (1990).

7) Preyer-S, Luckhaupt-H, Laryngol Rhinol Otol Stuttg., 66, 107-109 (1987).

8) Renzi-R, Finkbeiner-S, Am. J. Emerg. Med., 9, 551-552 (1991).

9) Davey-PG, J. Antimicrob. Chemother., $22 \mathrm{Su}-$ ppl C, 97-107 (1988).

10) Powell-JR, Donn-KH, J. Clin. Gastroenterol., 5 Suppl 1, 95-113 (1983).

11) Bell-J, ANNA J., 20, 187-188 (1993).

12) Sauvet-P, Schouler-L. Rev. Med. Interne., 13, 359-363 (1992).

13) Furst-DE, Am. J. Med., 13, 77, 51-56 (1984).

14) Urien-S, Albengres-E, Tillement-JP, Int. J. Clin. Pharmacol. Ther. Toxicol., 19, 319-325 (1981).

15) Landes-BD, Petite-JP, Flouvat-B, Clin. Pharmacokinet., 28, 458-470 (1995).

16) Albengres-E, Urien-S, Kusmierek-J, Tillement-JP, Eur. J. Rheumatol. Inflamm., 5, 87-97 (1982).

17) Porter RS, Sawyer WT, "Warfarin” In Applied 
Pharmacokinetics. 3 rd ed., by Evans WE et al Applied Therapeutics Inc., Vancouver, 1992, pp 31-1-31-46.

18) Rehnqvist, N. Serafimerlasarettet, Acta. Med. Scand., 204, 335-336 (1978).

19）高瀬幸次郎, 淵田則次, 青沼宏深, 小林道生, 山田昌信, 山本真由美, 為田勒彦, 中野越, 小 坂義種,“肝臓” 1986, 27-12, 1728-1732.

20）上塚芳朗, 高田誠, 溝部宏毅, 田中直秀, 栗原
毅，広沢弘七郎, $I C U$ と $C C U, 11-10,971-976$ (1987).

21) Adler, E. Louisville, Univ. Arch. Intern. Med., 146, 1837-1839 (1986).

22) Kojiro Takase, Hiromichi Fujioka, Makoto Ogasawara, Hiromi Aonuma, Yukihiko Tameda, Takeshi Nakano, 三重医学, 40-1, 27-32 (1990). 